\title{
Big "G" and Small "G": The Variable Geometries of Educational Governance in an Era of Big Data
}

Tavis Jules

Loyola University Chicago, tjules@luc.edu

Follow this and additional works at: https://ecommons.luc.edu/education_facpubs

Part of the Education Commons

\section{Author Manuscript}

This is a pre-publication author manuscript of the final, published article.

\section{Recommended Citation}

Jules, Tavis. Big "G" and Small "G": The Variable Geometries of Educational Governance in an Era of Big Data. The Educational Intelligent Economy: Big Data, Artificial Intelligence, Machine Learning and the Internet of Things in Education, , : 15-32, 2019. Retrieved from Loyola eCommons, Education: School of Education Faculty Publications and Other Works, http://dx.doi.org/10.1108/S1479-367920190000038002

This Book Chapter is brought to you for free and open access by the Faculty Publications and Other Works by Department at Loyola eCommons. It has been accepted for inclusion in Education: School of Education Faculty Publications and Other Works by an authorized administrator of Loyola eCommons. For more information, please contact ecommons@luc.edu.

\section{(c) (i) $\ominus$}

This work is licensed under a Creative Commons Attribution-Noncommercial-No Derivative Works 3.0 License. This article is (c) Emerald Publishing Limited and permission has been granted for this version to appear here. Emerald does not grant permission for this article to be further copied/distributed or hosted elsewhere without the express permission from Emerald Publishing Limited. 


\title{
CHAPTER 1
}

\section{BIG "G” AND SMALL “G”: THE VARIABLEGEOMETRIES OF EDUCATIONAL GOVERNANCE IN AN ERA OF BIG DATA}

\author{
Tavis D. Jules
}

\begin{abstract}
With the advent of the fourth industrial revolution and the intelligent economy, this conceptual chapter explores the evolution of educational governance from one based on governing by numbers and evidence-based governance to one constituted around governance by data or data-based educational governance. With the rise of markets and networks in education, Big Data, machine data, high-dimension data, open data, and dark data have consequences for the governance of national educational systems. In doing so, it draws attention to the rise of the algorithmization and computerization of educational policy-making. The author uses the concept of "blitzscaling", aided by the conceptual framing of assemblage theory, to suggest that we are witnessing the rise of a fragmented model of educational governance. I call this governance with a "big G" and governance with a "small g." In short, I suggest that while globalization has led to the deterritorializing of the national state, data educational governance, an assemblage, is bringing about the reterritorialization of things as new material projects are being reconstituted.
\end{abstract}

Keywords: Big "G”; small "g”; Big Data; Educational governance; Intelligent economy; Comparative and international education 


\section{INTRODUCTION}

Today, data is heralded as the "new oil" of our generation and a vital curator of the so-called "Intelligent Economy" that is premised upon the application of intelligent algorithms, knowledge, innovation, and the internet economy (see Fig. 1). The transition from governments to markets and the evolution of marketbased economies to knowledge-based economies implies that the new sources of wealth are intelligence in the form of information housed in clouds, harnessed through data procedures, broken down into uniquely tailored bites, and sold off to the highest bidder. The algorithmization and computerization of educational policy-making have arrived, and it is differentiated by data-driven governance (as opposed to evidence-based policy-making) where data is now multimodal; the source, analysis, output, and evaluator. With the progression of cloud computing, we have witnessed the arrival of the "measurement generation" which counts in zettabytes (one-sextillion bytes), yottabytes (one-septillion bytes), brontobytes (one-octillion bytes), and geopbyte (one-nonillion bytes). In today's internetdriven industrial revolution, or the so-called Fourth Industrial Revolution, data in any of its 13 forms - Big Data, ${ }^{1}$ structured, unstructured, and semi-structured data, ${ }^{2}$ time-stamped data, ${ }^{3}$ machine data, ${ }^{4}$ spatiotemporal data, ${ }^{5}$ open data, ${ }^{6}$ dark data, ${ }^{7}$ real-time data, ${ }^{8}$ genomics data, ${ }^{9}$ operational data, ${ }^{10}$ high-dimension data, ${ }^{11}$ unverified outdated data, ${ }^{12}$ translytic data, ${ }^{13}$ (Bridgwater, 2018; Huang \& Jin, 2018; Li, Feng, Chin Ooi, Wang, \& Zhou, 2011) - is multiplying as it digitally transforms the ways in which we live, work, govern, and educate. This new economy is energized by digital technologies and has at its core intelligent machines and sensors ranging from self-learning algorithms to interconnected devices. As the parameters of innovation evolve, we are witnessing the transition from the technological paradigm of the knowledge-based economy to industry 4.0, which is characterized by the integration of Big Data with the production process (OECD, 2018). With the move from the linear economy to the circular economy, the race to denominate machine learning, a subfield of artificial intelligence, is energized by who can commodify, consume, and customize the most significant amount of data for clients.

With the emergence of this new oil, questions around data privacy have arisen in the wake of several scandals (ranging from social [Facebook], to military [Fitness App Polar], to political [Cambridge Analytica Ltd.]) as to who governs the different aspects of data. Following Cope and Kalantzis (2016), Big Data in education is viewed as

the purposeful or incidental recording of activity and interactions in digitally mediated, networkinterconnected learning environments - the volume of which is unprecedented in large part because the data points are smaller, and the recording is continuous. (p. 2, emphasis in original)

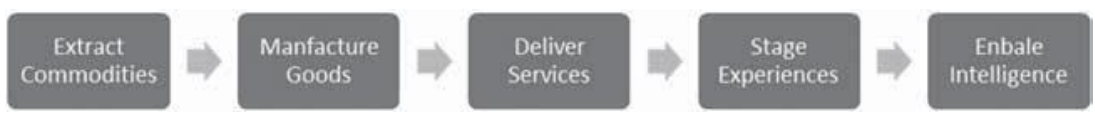

Fig. 1. The Intelligent Economy. 
While these discussions have now come to the forefront of national and global policy agendas, the impact of data governance on the educational sector has rarely been discussed. When data governance and education are talked about in the same vein, they are always linked to workforce development, educational data mining, and learning analytics (Cope \& Kalantzis, 2016; Gagliardi, Parnell, \& Carpenter-Hubin, 2018; Williamson, 2017) or the ways in which disruptive innovation has challenged the orthodoxy of the classroom (Christensen, Horn, \& Johnson, 2008).

The amount of data collected and mined about why students perform better in some international tests over others means that Comparative and International Education is now big business. For example, in the USA, in 2017, \$2.7 billion was invested into ed-tech companies (up from $\$ 1.6$ billion in 2016) by venture-capital investors, while millions have been spent on implementing technology-based personalized learning by the Silicon Valley Community Foundation, the Gates Foundation, and the Chan-Zuckerberg Initiative (Atlantic, 2018). With the rise of markets and networks in education, Big Data, machine data, high-dimension data, open data, and dark data have consequences for the governance of national educational systems. For the last few decades, "educational governance tools" (Jules, 2012) and "governance mechanisms" (Dale, 1999) (as opposed to markets or hierarchy) have gained legitimacy as they "organize and carry out governing interactions in the face of diversity, complexity, and dynamics" (Kooiman, Bavinck, Chuenpagdee, Mahon, \& Pullin, 2008, p. 5).

The role of the state is changing, and in instances where the state has been perceived as failing in its governance responsibility, new actors have entered the conversation, and in education these actors now include public-private partnerships that use "interactive governance" by seeking "to solve societal problems and to create societal opportunities; including the formulation and application of principles guiding those interactions and care for institutions that enable and control them" (Kooiman et al., 2005, p. 17). In other words, we are now in an era in which governing is akin to governance and the "public" is replaced with the "private" as part of hybrid partnership configurations involving state and nonstate actors (Ball, 2019; Levi-Faur, 2012; Robertson, Mundy, Verger, \& Menashy, 2012). As Jules (2017) suggests, this now implies that the global educational policy environment is gated, regulated, and "over" governed since "newer actors" or "education brokers" are advancing a different set of educational governance mechanisms and several newer modus operandi (or modes, styles, and arrangements) of governance - collaborative governance, ${ }^{14}$ interactive governance, ${ }^{15}$ network governance, ${ }^{16}$ global experiential governance, ${ }^{17}$ meta-level governance, ${ }^{18}$ performance-based governance, ${ }^{19}$ evidence-based governance, ${ }^{20}$ and data-driven governance - which have the ability to make decisions in real time. In this way, educational governance mechanisms have orthodoxly been viewed as driven by external policy mechanisms of influence; however, the combination of technology and data is revolutionizing educational decision-making processes and educational governance.

Thus, I am suggesting that with the adoption of new technologies, Big Data is reterritorializing educational governance. These new territories are global in 
scope, scale, and dynamics since today's national policy environment is multiscalar, multispatial, and multilayered and guided by new state and non-state actors. With the movement to a student-as-customer model in education, educational systems are now capturing consumer behavior and preferences to make analytical predictions about what and how to govern. In what follows, I first highlight an overview of the historical archives and dissemination of data in comparative education by "international knowledge banks" (Jones, 2007). Next, I explore how the transition from data collection to data-based evidence policymaking has respaced national educational governance. In the second half of the paper, I use the concept of "blitzscaling" aided by the conceptual framing of assemblage theory to suggest that we are witnessing the rise of a fragmented model of educational governance. I call this governance with a "big G" and governance with a "small g." In short, I argue that while globalization has led to the deterritorializing of the national state, data educational governance, an assemblage, is bringing about the reterritorialization of things as new material projects are being reconstituted.

\section{HISTORY OF DATA COLLECTION AND GOVERNANCE IN COMPARATIVE AND INTERNATIONAL EDUCATION}

In Comparative and International Education (CIE), Maroy (2009) asserts that "governance models" indicates "theoretical and normative models serving as cognitive and normative references, especially for decision-makers, in defining 'good ways to steer or govern' the education system" (p. 76). The collection, commodification, and consumerism of data in CIE is nothing new, and has been done since the World Bank's first educational loan to Tunisia in 1962, and has been used in large part to drive data-based decision-making and evidence-based policy-making choices ever since. Under these strategic priorities that highlighted evidentiary policy-making, governments lacked the analytical policy capacity to manage the policy process, and these were then outsourced to "international knowledge banks" (Jones, 2007), such as the World Bank and the International Monetary Fund, which later applied loan conditionalities to education. This is described by Jones (2007) as the rise of "educational fundamentalism" that later transformed into "educational multilateralism" (Mundy, 1998) and now exists as mechanisms of coordination under "educational regionalism" (Jules, 2015). With the movement toward the assessment of educational opportunities, outcomes, monitoring, and the production of reports, we have entered an era defined and driven by digital educational products and services.

\section{Data Collection and the International Evaluation of Educational Achievement (IEA)}

One of the oldest data collection, commodification, and consumerist entities in CIE is the IEA, which was created in the late 1950s and conducted its first 
assessment of learning in the early 1960s (Lindblad, Pettersson, \& Popkewitz, 2018). Prior to IEA,

comparing education had been undertaken more from out of humanistic ideals, but with the formation of the IEA by scientists with interest in psychometrics and with an outspoken interest in educational outputs, social sciences and behavioral science came to be the ideal on which comparative achievement tests rested. (Lindblad et al., 2018, p.3)

Today, IEA uses country-based sampling and is one of the largest collectors of educational data in the form of large-scale comparative studies on policy, curricula, and student outcomes. IEA's large-scale international assessment (ILSA) data and other studies are made accessible to researches through its online "Gateway." ILSA's data play a pivotal role in providing economic and social policy guidance to countries (Mølstad \& Pettersson, 2018). As Lindblad et al. (2018) further state,

[...] the IEA created something new in the history of comparing education. It focused on educational output that could be represented in numbers: they created hierarchies of students and educational systems as well as nations based on these numbers, and as a result, IEA created specific positivistic reasoning on education. (p. 4)

IEA's advancement into the collection of educational data began with the First International Mathematics Study (FIMS), conducted in 12 countries in 1964, which featured samples of 13-year-old students and pre-university students and focused on how teaching and learning in mathematics influences societal, scientific, and technological change (IEA, 2019). While FIMS at this point focused solely on mathematics, its overall aim "was to examine the differential output of school systems, using achievement in mathematics as the independent variable" (Robitaille, 1990, p. 396). Data for FIMS led to the Second International Mathematics Study (SIMS), which was conducted in 22 countries in the early 1980s and also assessed students aged 13 and those who were finishing their secondary schooling (Horvath, 1987). As IEA (2019) suggests, the aim was to examine mathematics education in middle schools across three dimensions: curricula, classroom practices, and student achievement in the final year of schooling. In the early 1990s, the Computers in Education Study (COMPED) collected data on the impact of the introduction of computers in participating countries. Around the same time, the 1990-1991 Reading Literacy Study, conducted in 32 countries, began mining data and using it to have states enact evidence-based, data-driven decision-making.

Beginning in 1995, IEA and the United States by way of the National Center for Education Statistics (NCES), began collecting data for the Trends in International Mathematics and Science Study (TIMSS) (1995, 1999, 2003, 2007, 2011, and 2015) and the TIMSS Advanced (1995, 2008, and 2015), conducted as a follow-up to previous assessment studies in mathematics and science (Mullis \& Martin, 2017). TIMSS, as an assessment dataset which measures three components, "the intended curriculum, the implemented curriculum, and the attained curriculum" to understand educational opportunities, is a "valuable resource for monitoring educational effectiveness because (STEM) science, technology, engineering, and mathematics ... are key curriculum areas" (Mullis \& Martin, 2017, pp. 3-4). The data collected on educational opportunities focused on explaining 
whether or not national educational systems have done a good job of customizing their educational offerings by measuring

what is actually taught in classrooms, the characteristics of those teaching it, and how it is taught; and, finally, what it is that students have learned and what they think about learning these subjects. (Mullis \& Martin, 2017, p. 4)

Today, TIMSS data from fourth- and eighth-graders are collected, mined, and subjected to predictive analytics in approximately 60 countries that pick a nationally representative sample of students at each grade level, amounting to nearly 150 schools and one or more intact classes per grade, and some 4,000 students (Mullis, 2017). By 1999, and then in 2016, The Civic Education Study (CivEd) and International Civic and Citizenship Study (ICCS) were administered to ninth-graders to measure their knowledge of democratic practices and institutions, as well as the role of citizens in 27 countries.

In 2001, IEA, in collaboration with the U.S. Department of Education's National Center for Education Statistics, began the Progress in International Reading Literacy Study (PIRLS), which is administered every five years in a growing number of countries to measure reading for fourth-grade students. The PIRLS assessment data is composed of a reading assessment and a questionnaire focused on addressing students" "reading attitudes and habits." This data is marketed as being able to provide students, teachers, and school principals information about literacy practices. This data also had a benchmarking feature which provided information on how U.S. students compare around the globe in literacy. The most crucial data product of the PIRLS is the post-assessment report which contains

reading achievement results for the participating countries and benchmarking entities, shows trends over time for the countries and benchmarking entities that also participated in previous assessments, and relates reading achievement to a number of home, school, and classroom contexts for learning to read. (Martin \& Mullis, 2013, p. 2)

By 2006, the data on the mathematics preparation of future primary and secondary teachers through the Teacher Education and Development Study in Mathematics (TEDS-M), and pedagogy and information and communication technology (ICT) use in schools through the Second Information Technology in Education Study (SITES), saw IEA expanding its data harnessing power.

\section{Data Collection and the Organisation for Economic Co-operation and Development (OECD)}

Schooling and education are becoming increasingly globalized, and the OECD has become the prime driver for global educational governance. The OECD, established in 1961, is one of the largest compilers, codifiers, and consumers of educational data under its data-driven policy-making strategies. The OECD collected data from the International Adult Literacy Survey (IALS) in 1994, 1996, and 1998, in thirteen countries to measure adult literacy skills (Paccagnella, 2016). As Hamilton and Barton (2000) note, IALS had three aims that focused on "produce[ing] meaningful comparisons between countries, to understand the 
relationship between literacy and economic indicators of wealth and wellbeing, and to inform and influence policy decisions" (p. 378). Participating countries, which assess three separate domains of literacy (prose literacy, document literacy, and quantitative literacy), were instructed to make available a probability sample of individuals aged 16 to 65 (Darcovich, 1998; Thorn, 2009). Prose literacy data was collected on "knowledge and skills needed to understand and use continuous texts - information organized in sentence and paragraph formats" while document literacy data described "the knowledge and skills needed to process documents, or information organized in matrix structures (i.e., in rows and columns)" and quantitative literacy data "covered the skills needed to undertake arithmetic operations such as addition, subtraction, multiplication, or division either singly or in combination using numbers or quantities embedded in printed material" (Thorn, 2009, p. 10).

In 1997, the OECD began collecting comparable student data on performance science, mathematics and reading cross-nationally. In 2000, the triannual Programme for International Student Assessment (PISA) began and since then, in more than 90 countries, data is collected on the skills and knowledge of 15 -yearold students nearing the completion of their compulsory studies. This information is collected from a range of direct (questionnaires) and indirect (government data) sources in collaboration with other international organizations (Eurostat and United Nations agencies). This then allows the OECD to work with these organizations in providing governance, guidance, and directions to client countries. PISA data aims at establishing benchmarks in three areas by collecting information on baseline indicators on student's skills and knowledge; demographic, social, economic comman and educational statics; and student-level, school-level, and system-level background data on the connection between outcome levels and distributions (OECD, 2017). Today, PISA data is offered as governance guidance in an A la carte treasure trove of data on "comparative listings of the country mean performance" in the form of "student attitudes and perceptions related to schooling, home background variables, and school information" (Anderson et al., 2007, pp. 591-92).

In 2008, data from over 100,000 randomly selected lower secondary school teachers was gathered on collaborating with school leaders, student assessment practices, working conditions, and learning environments by The Teaching and Learning International Survey (TALIS) survey. Data were collected in five areas: "school policies supporting effectiveness; developing teachers within the profession; effective teachers and teaching; attracting teachers to the profession; and retaining teachers in the profession" (Ainley \& Carstens, 2018, p. 8), toward TALIS's comparative insights on teaching and learning school conditions, school leadership, their preparation and professional development, and feedback and appraisal (Schleicher, 2011). Since its inception, this large-scale international survey has moved from assessing data in 24 countries to 34 countries, and also added new indicators on team leadership, and expanded its surveying to teachers in primary and upper secondary schools (OECD, 2016). In 2012, 2014, and 2017 the Programme for the International Assessment of Adult Competencies (PIAAC), a computer-based assessment, gathered data from peoples aged 16-65 in 40 
countries/economies. The data contains information on the skills adults need to participate in society and the economy. This information, based on interviews with a sample size of between 3,700 and 27,000, is derived for measuring critical cognitive and workplace skills ranging from critical information-processing skills - literacy, numeracy, and problem-solving (Liu, 2018). OECD's governing by numbers promoted market fundamentalism, competition, and other forms of neoliberal reforms under the semblance of "best practices" and educational reform packages.

\section{Data Collection and UNESCO Reports}

In the 1960s and 1970s, UNESCO established itself as the premier destination for educational data, but this waned by the 1980s once the USA withdrew from the organization (Heyneman, 1999). The launch of the World Education Report in the 1990s was an attempt to rebrand UNESCO as a "global intellectual forum" (Mundy, 1999, p. 43) with the ability to collect, sort, monitor, and analyze data from its flagship projects - the World Education for All (WCEFA) co-sponsored by the United Nations Development Programme (UNDP), the United Nations Children's Fund (UNICEF), the United Nations Population Fund (UNFPA), the World Bank, and the 2000 World Education Forum. Formerly known as the Education for All Global Monitoring Report, the Global Education Monitoring Report (GMR) is an annual UNESCO report which collects and compiles data, evidence, commissions' research, and background papers on education targets in the new Sustainable Development Goals. As the UNESCO (2019) report suggests, the GMR

serves as an invaluable global resource and advocacy tool, promoting informed dialogue and increasing public awareness of education's central role in achieving sustainable development, and the challenges to achieving quality, equitable and inclusive lifelong learning for all by 2030. (para. 3)

This sense of validity given to the GMR was derived from the creation, monitoring, production and commodification of educational data since the 2000s with the launch of the Education for All reports in 2002 to assess cross-national data on the progress being made toward EFA. As Edwards, Taeko, Da Costa, and Kitamura (2018) argue, UNESCO used its coordination of the EFA to regain its legitimacy, and it can also be suggested that it is now using GMR data as a governance mechanism to keep this legitimacy. Edwards et al. (2018) further argue that from the initial report of 51 pages in 2002, by 2010, the thematic analysis covered some 525 pages using a country-by-country data reporting approach. From 2009 to 2015, GMR sought to influence global policy governance by utilizing a topical, rather than a thematic, approach to data-driven policy. In fact, "at international and national levels, the GMR provides advocacy stakeholders with valuable and credible evidence to feed into their materials and activities" (Education for Change, 2014, p. viii). More importantly, educational governance is also becoming circular as many of the so-called thought leaders in education and epistemic communities sit on the advisory boards of the organizations that ultimately drive policy decisions. 


\section{GOVERNANCE IN AN ERA OF DATA SERVITIZATION}

During the 1990s, a coalescing of material agencies (UNESCO, World Bank, UNDP, UNICEF, and OECD) began to push a global education agenda that focused on the collecting, minding, benchmarking, and disseminating of educational data under the guise of "best practices" and "good governance" to improve school access, quality, equity, accountability, and efficiency. With the creation of the World Trade Organization in 1995 and the establishment of the General Agreement on Trade in Services (GATS), education evolved to encompass four modes of supply (cross-border supply - distance education; consumption abroad traveling for services; commercial presence - offshore services; and the presence of natural persons - external service provisions). Under the four modes of supply, education became structured by the neo-classical philosophies that underscore managerialism, corporatism, and neo-Taylorism and governance policies placed emphasis on competition, benchmarks, indicators, and assessments. Thus, rational actors (state and non-state correspondingly) diagonally operate multilevel across policy systems that utilize different educational governance tools or mechanisms (funding, provision, ownership, and regulation), across distinctive scales (local, regional, and global) delimited by the division of labor and incubation of GATS.

The movement from knowledge, which was the central component of the knowledge-based economy, toward innovation, dominated and defined by the integration of complex technologies under the banner of the Fourth Industrial Revolution, coupled with the rise of educational brokers (new state and nonstate actors) using several newer modus operandi of governance, has drastic consequences for national educational systems. This is compounded by the alteration toward servitization defined by the drive toward "product-as-a-service providers" (Jules, 2016; Probst, Frideres, Cambier, Ankeraa, \& Lide, 2016). ${ }^{21}$ The ability to harness and plan policy based on data-driven management has accelerated the movement toward servitization, which is the central component of the global market economy. Educational data-driven governance evolved to capture the beginning of the servitization of the educational sector. In short, with the arrival and application of data mining techniques through the use of machine learning, statistics, and database systems to an educational data, we are witnessing the last trend toward the advent of education as a service as defined by the creation of digital products.

Parreira do Amaral $(2006,2010)$ argues that the shifting trajectory of governance without government is transforming education policy. In other words, innovations that have been restricted to the technology sector are gradually starting to move into education as companies seek to monetize social data, dark data, and Big Data. The so-called disruptive innovation that has plagued other sectors (i.e., hotel [Airbnb], taxies [Uber], brick and mortar stores [Amazon and EBay], Television, Netflix; classified ads [Craigslist], newspapers [Twitter] and research libraries [Google]) and created the peer-to-peer marketplace has now entered the educational industry. For example, this trend commenced with the rise of Massive Open Online Courses (MOOCs) open learning management systems and 
Personal Learning Environments (PLEs), and an evaluative culture for students and faculty led by data-driven teaching and learning. MOOCs, the pedagogical modes of Connectivism and Connective Knowledge (CCK), is viewed as replacing the orthodoxy of "place-based" teaching modes (Abu Mezied, 2016). MOOCS was the creation of a small tool, using real-life data to provide meaningful interactions FROM the comfort of one's home. This data is then turned into information. Although teaching and learning processes are too multifaceted to automate, Big Data is codifying the basic standards for teaching and assessment and translating these into performance and evaluation frameworks for schools and teachers. Open learning management systems have gained traction in recent years with the rise of eLearning as students and teachers are given tools to improve learning processes. With the movement toward the student-as-client model, faculty and student evaluations have been moved to the forefront of evidence-based policymaking.

With the advent of digitization and the domination of global economics with information and communication technologies, the orthodoxy of nine-to-five full time employment is being displaced and replaced with the "freelance economy" - the ability of employees to work remotely or from home; the "gig-economy" or "agile economy" - temporary and flexible jobs for independent contractors; the "open talent economy" - the use of networks and ecosystems; the "sharing economy" or "collaborative economy"- the ability to temporarily rent or borrow the assets from peer-to-peer; and the "on demand economy" or "access economy" - the capacity to access products and services (Jules \& Sundberg, 2018). Today, data-driven educational governance exists within the "experience economy", where it is about a client-service relationship that is shaped by growing customers' distinctively unique packaged experiences. The shift away from knowledge and toward 21st Century Learning Skills - communication, creativity, collaboration, and critical thinking has allowed for the customization and personalization of client recommendations and products, ordered and delivered virtually to the client's proverbial "front door." Of course, these trends raise issues of data protection and grandiose policies, such as the European Union's General Data Protection Regulation (GDPR), which seeks to harmonize data privacy laws.

\section{BLITZSCALING: TOWARD EDUCATIONAL BIG DATA GOVERNANCE AS A COMPLEX ASSEMBLAGE}

Educational data is all around us; we have only now truly begun to mine, harness, disseminate, abuse, and customize data for markets, consumers, and product placement purposes. In business, blitzscaling is used to describe the herd mentality of conquering through a "winner-takes-all markets", or what amounts to high-speed land grab (Economist, 2019). In education governance, we are now seeing the surge of blitzscaling as new educational brokers are using newer modus operandi governance instruments as they clash with the hegemonic powers of a devolved herculean state that is fighting for legitimacy. In this new high-speed land grab of governing governance, I want to suggest that we are witnessing the 
evolution and splintering of two forms of educational governance with the rise of the intelligent economy that privileges servitization. In essence, blitzscaling in education has led to the arrival of "techno-solutionism" (Economist, 2018), where problems in health and education are viewed as solvable with the application of technology (of which today's favorite is blockchain, which is linked through cryptography) (Economist, 2018).

One way of thinking of proliferation of data, with its micro, meso, and macro ecosystems, in an era of blending types of governance and the emergence of the intelligent economy, is to frame data as an assemblage. By assemblage, deference is given to De Landa (2006) who argues assemblages lie on a continuum ranging from purely material to expressive. As an imaginary, assemblages have a "degree of internal homogeneity ([territorializiation] or a degree of sharpness of its boundaries to destabilize it [(derritorializiation]"'(p. 12). In this way, today's datafication process is one of territorialization that is driven by predictive analytics and client-centered relations, which can be referred to as a "non-spatial process which increases the internal homogeneity of an assemblage" (De Landa, 2006, p. 13). Thus, the focus is on the interaction, flow, and distinctive features of the process of governance in an era of data; that is, this new datafication trend engenders reterritorialization of educational governance. Reterritorialization because data is all around us and it is located in the physical locale while simultaneously being part of and scaled to different assemblages. Not all data, either fragmented or fluid, is the same. However, given that the internationalization of data has been in the field of CIE since its inception, then it must be viewed as an arrangement, and it has thus shaped the field. While data is not the primary assemblage in the field of CIE, it is but one assemblage within a set of educational assemblages that exert power over and within other assemblages. Thus, data as an assemblage informs regulated decision-making in institutions, such as IEA, OECD, and UNESCO given the codependency that these entities exert over one another. In this way, data as the primary object is a conceptual apparatus stemming from the interaction of open systems with other elements occupying a common field in contingent interrelationships. Data as an assemblage focuses our attention on the always emergent present while preserving the concept of structure. As an assemblage, Data is structured by Laney's (2001) “3V” of volume, variety, and velocity where its constituent relational elements

$[\ldots]$ are thus the causally productive (machinic) result of the intersection of two open systems, and their properties are emergent in the sense in which that concept is deployed in logic, that is, not part of, and so not foreseeable in light of, either one or the other system considered in isolation, but instead only discernible as a result of the intersection of both such systems. (Marcus \& Saka, 2006, p. 103)

Educational data governance is then a composite project that draws attention to its interactions with, and its ability to plug into, different mechanisms (social, economic, and political) allowing its relationship to change while its term remains stagnant (De Landa, 2006). From an assemblage perspective, data's "relation of exteriority" enable it to be taken apart while at the same time creating synthetic interactions between other material parts, and thus enabling 
it to co-evolve (De Landa, 2006). Data is an assemblage in that it establishes unstable interactions as it coevolves with other elements, and thus becomes both the product of multiple determinants and the space of the assemblage that it inhabits. In this context, we see the rise of what I will call data-driven governance in education that can be split as governance with a "big G" and governance with a "small g."

As part of an assemblage (in the Deleuzian sense) the arrival of data as the new oil implies that education governance now resembles "Big G" practices, which is a "meta-steering" in the form of "strategic coordination" (Jessop, 2000) or meta-governance, which consist of the "coordination of coordination" (Dale, 2005); and "small g" which is responsible for the regulation, ownership, provision, and funding of national educational projects. Thus, the historical process of governance is embedded within a matrix of larger institutional practices surrounded by discursive language.

With the rise of the "comparative turn" - the numericalizaion of educational systems - by international knowledge banks, education governance entails "a scientific approach to political decision making" (Martens, 2007, p. 42) where numbers and statistics are viewed as a "beacon of objectivity, a promise of incorruptibility" (Porter, 2018, p. 24) that is above self-interested agendas in an evaluative culture driven by figures, reports and studies. Today's "spaghetti bowl" (Bhagwati, 1995) of educational governance is devised of "multiple and concurrent participation by governments in different educational agreements across various levels (supranational and global) in today's multi-stakeholder governance environment" (Jules, 2018, p. 140). In this way, educational providers (state or nonstate or hybrid models) are using "small g" modus operandi of governing systems or governance interventions concurrently with innovative types of educational governance mechanisms. As Jules (2015, 2017) suggests, "governance modes" are theoretical, and normative models are serving as cognitive and references, especially for decision-makers, in defining the best strategies for the steering or governing of education systems. In essence, the sources "small g" are different from the agents "Big G." By Big G, we imply that the actions of states are now defined not by

cede[ing] their claim to sovereignty in the face of growing complex interdependence and seek to enhance their political capacities by participating in hierarchic coordination mechanisms or devolving some activities to private institutions and actors, [that would] seek to shape and steer these mechanisms through meta-steering practices. (Jessop, 2000, p.53)

One way of conceiving the split in educational governance is through historical institutionalism which suggests that "once policies and organizations are created these structures will persist until some major event - a punctuation in the equilibrium - occurs" (Peters, 2011, p. 8). This point is best illustrated in the arrival of market mechanisms in education in the $1980 \mathrm{~s}$, which gave rise to the horizontal management where educational governance moved toward the "coordination of differentiated institutional orders or functional systems" or "decentred, context-mediated intersystemic steering" (Jessop, 1998, p. 30). In other words, the emergence of "digital Taylorism" or "New Taylorism" in education 
"enables work activities to be dispersed and recombined from anywhere around the world in less than the time it takes to read this sentence" (Brown et al., 2011, p. 72).

The shift toward "big G" in education, implies that the movement from governance to meta-governance (later called meta-steering) now relies on the complex coordination interdependence, which Jessop $(1998,2000)$ suggests uses "higher-order mechanisms to calibrate different modes of steering (markets, states and other forms of imperative coordination, networks)" (p. 2000, p. 334) to achieve policy outcomes and priorities that are dictated by coordinating league tables, rankings and other international comparative target achievements (ICTAs) (Meyer \& Benavot, 2013) that is now a facet of the "global education industry" ([GEI], Ball, 2012, 2019; Steiner-Khamsi, 2016). ${ }^{22}$ In education, "big G," has utilized coordination and collaboration, which are "both driving force(s) of governance and one of its goals" (Bevir, 2009, p. 56). In this way, it is about network management of meta-steering to achieve strategic actions and network interaction which are driven by interdependence. The arrival of variable instruments of governance processes has signaled that "big G" is now a selfregulated ecosystem that is actor driven. This is illustrated in the 17 goals of the Sustainable Development Goals (SDGs). Nevertheless, technological-driven disruption will only intensify as commercial drones, driverless cars, artificial intelligence, quantum computing, mobile streaming, and new types of medicine are evolving.

From a governance perspective, the intelligent economy is founded on what Revel (n.d.) calls "economic intelligence," which combines several concepts and practices including "competitive intelligence, economic security, risk management, lobbying, public diplomacy, soft power (governments), business diplomacy (companies)" to regulate the flow of information among public and private actors. As a governance mechanism, economic intelligence is "recognized as a professional tool for strategy and management for states and companies in the globalized world" (Revel, 2010, p. 2). Thus, within the intelligent economy and both individual and system-level, processes are giving way to "educational intelligence," which focuses on innovation to harness, manage and steer data integration found in cloud computing, social media, mobile and automation technologies, and scientific discoveries. The rise of educational intelligence means that clients (countries, organization, and other stakeholders) are plied with cutting-edge data in the form of predictive analytical patterns (modeling, machine learning, and data mining of historical data), and knowledge about global educational predictions of future outcomes and trends. Within the new temporal space of the neoliberal imaginary driven by markets and networks, educational brokers are now mining data and detecting patterns to amplify the value of data.

In summary, what started as sample cross-nation data collection to better understand how national education systems are preformatting against each other has now turned into a booming multitrillion-dollar knowledge-based enterprise where regimes, such as the IEA, OECD, and UNESCO are seen as thought leaders on several cross-national educational issues. This has meant 
than non-educational players (consulting firms such as McKinsey \& Company and KPMG think tanks, and foundations) are also entering the data collection markets competing against each other for larger market shares. In short, international data sets run by educational brokers, such as IEA, OECD, and UNESCO "provide individual countries with the impetus to improve students' academic achievement in different subject areas through information derived from cross-national scales of comparison" (Hong, 2012, p. 3). These historical data factories above have demonstrated that national government uses the data collected to inform and shape how everything from how subjects are taught in classes to how and what types of training teachers should have, and the type of policy reforms that national governments should preference and privilege. As Steiner-Khamsi(2014) suggests, "policy analysts in other countries only emulate the system features of league leaders" (p. 153) which has been the orthodoxy in educational data governance by IKBs. Of course, it is the glossy reports and the attention-grabbing headlines that give these educational data sets their legitimacy and power over the politics of educational governance.

The transition from the so-called knowledge-based economy toward the "Educational Intelligent Economy," which is premised upon the application of knowledge, has implications for the field of Comparative and International Education. Historically, most of the comparative data collected was for either assessment (IEA), evaluation (OECD), monitoring (UNESCO), or policy recommendations (IKBs). However, data collection is shifting as national governance postures change. In most fields, the customizing, commodifying, and consuming of data is a permanent feature of the post-millennium era. What remains clear is that as educational governance, driven by standardization, regulation, and predictability through the codification of intelligence, impacts how data is collected, consumed, and commodified, it has severe repercussions for national educational systems. Data is itself caught up in the glossy headlines that seek to advocate for one type of policy reform over another.

\section{NOTES}

1. This includes very large and diverse data sets that are composed of structured, semistructured, and unstructured data for different sources. It is also the building blocks for Artificial Intelligence and the Internet of Things IOTs).

2. Respectively, this is data that has been formatted, has some organization properties, or is in pre-defined manner.

3. This is behavioral data that is collected, data that exists within temporal windows. Time-stamped data can also be utilized concurrently with geographically specific data sets.

4. Information generated from real-time recording of networked devices (such as IOTs), embedded systems, mobile phones, and computers across technologies and digital infrastructure.

5. Generates spatial and temporal changes in data in a physical location over time. Spatiotemporal data can be broken down into querying methods: split and coupled. Split usually targets objects that satisfy some spatial constraints within a period of time or vice versa. The data satisfies the spatial constraints independent of historical data as long as the data belong to the given time domain. Coupled usually targets objects that satisfy 
some (sequential) spatial constraints over a period of time. Series of consecutive or nonconsecutive constraints are part of a query.

6. Data freely available that can be reproduced. The open data movement has two principle goals: to increase citizen participation in public management to foster transparency and accountability; and create new services and products by combining public data with other datasets to foster innovation and creativity.

7. Unused or dormant data. "Dark data" is not carefully indexed and stored so it becomes nearly invisible to scientists and other potential users and therefore is more likely to remain underutilized and eventually lost.

8. Data delivered instantaneously stemming the DNA of patients.

9. Data stemming from the DNA of patients.

10. The collection and integration of data from different sources to manage, report, and control operational decision support.

11. The use of eigenvectors to collet facial recognition of data.

12. Data that exists but has no defined purpose. Using unverified data, such as free internet sources that in turn may result in the giving of incorrect advice to clients can have disastrous consequences.

13. Data derived from real-time analytics of transactional data.

14. Kassim's (2016) Gender Equality (GE) Scorecard. Collaborative governance can be applied to notions of participatory governance and civic engagement and is founded on interactions among different components and elements of institutional research and policy models.

15. Interactive governance is viewed as "the complex processes through which a plurality of social and political actors with diverging interests interact in order to formulate, promote, and achieve common objectives by means of mobilizing, exchanging, and deploying a range of ideas, rules, and resources (Torfing et al., 2012, p. 2)" Interactive governance in education suggests that implementation structures, wherever located, will allow all actors to take part in the process.

16. Network governance is driven by the disruption of regulation and marketization of public services. A network governance lens allows for more nuanced understanding of the coordination and management of complex networks for tackling shared social policy issues, albeit not without the challenges discussed.

17. Coordiated civic action that uses the social dimensions to frame social policy. The European Open Method of Cooordiantion (OMC), based on voluntary cooperation that uses benchmarks, guidelines, indicators, and best practice, is an example of this.

18. Meta-governance (or better, meta-steering) is often perceived as the governance of governance. An earlier incarnation of meta-governance in education includes NPM and the attendant perceptions of neoliberalism and the Washington Consensus model.

19. Recently introduced performance-based governance systems and evaluation policies have incorporated NPM-style reform tenets, which have presented increasing ambiguities on how real-world evaluation organizations, processes, and measurements contributed to decision making both at the central and local level in politically charged policy domains (Marra, 2018).

20. Evidence and theory suggest that governance characterized by horizontally organized and collaborative partnerships between stakeholders, such as between a government agency and a private organization, may be more effective in achieving the conditions necessary to promote socially desirable outcomes than top-down hierarchical relationships between government agencies and their subordinates (see Kum, Joy Stewart, Rose, \& Duncan, 2015).

21. This term comes from the business world and it implies that manufacturers are moving away from a transactional approach of making and selling of goods to a relational approach based on providing product-centric services that are integrated within their products.

22. These include IEA, IALS, PISA, PIAAC, PIRLS, GMR, FIMS, SIMS, TIMMS, and TALIS. 


\section{REFERENCES}

Ainley, J., \& Carstens, R. (2018). Teaching and Learning International Survey (TALIS) 2018 conceptual framework. OECD Education Working Papers No. 187. Paris, France: OECD.

Ball, S. J. (2012). Global Education Inc.: New policy networks and the neo-liberal imaginary. London: Routledge.

Ball, S. J. (2019). Serial Entrepreneurs, Angel Investors, and Capex Light Edu-Business Start-Ups in India: Philanthropy, impact investing, and systemic educational change. In M. Parreira do Amaral, G. Steiner-Khamsi, \& C. Thompson (Eds.), Researching the Global Education Industry (pp. 23-46). London: Palgrave Macmillan.

Bhagwati, J. N. (1995). US trade policy: The infatuation with FTAs. Department of Economics Columbia University. Retrieved from http://doi.org/http://hdl.handle.net/10022/AC:P:15619

Bridgewater, A. (2018). The 13 types of data. Retrieved from https://www.forbes.com/sites/adrianbridgwater/ 2018/07/05/the-13-types-of-data/\#2da4c72f3362

Brown, P., Lauder, H., \& Ashton, D. (2010). The global auction: The broken promises of education, jobs, and incomes. New York, NY: Oxford University Press.

Christensen, C., Horn, M., \& Johnson, C. (2008). Disrupting class: How disruptive innovation will change the way the world learns. New York, NY: McGraw-Hill.

Cope, B., \& Kalantzis, M. (2016). Big Data comes to school: Implications for learning, assessment, and research. AERA Open. https://doi.org/10.1177/2332858416641907

Dale, R. (1999). Specifying globalization effects on national policy: A focus on the mechanisms. Journal of Education Policy, 14(1), 1-17.

Dale, R. (2005). Globalisation, knowledge economy and comparative education. Comparative Education, 41(2), 117-49.

Darcovich, N. (1998). Sample design. In S. Murray, I. Kirsch, \& L. Jenkins (Eds.), Adult literacy in OECD countries: Technical report on the first International Adult Literacy Survey (pp. 25-40), Washington, DC: U.S. Department of Education.

Economist. (2018). Billionaires and the Falcon Heavy: The mega-rich have ambitious plans to improve the world. Retrieved from https://www.economist.com/leaders/2018/02/08/the-mega-rich-haveambitious-plans-to-improve-the-world

Education for Change. (2014). External evaluation of the education for all global monitoring report: Final report. London. Retrieved from http://www.unesco.org/new/en/education/themes/leading-theinternational-agenda/efareport/advisory-board/

Edwards, D. B., Okitsu, T., da Costa, R., \& Kitamura, Y. (2018). Organizational legitimacy in the global education policy field: Learning from UNESCO and the Global Monitoring Report. Comparative Education Review, 62(1), 31-63.

Gagliardi, J., Parnell, A., \& Carpenter-Hubin, J. (2018). The analytics revolution in higher education: Big Data, organizational learning, and student success. Bloomberg, IN: Stylus Publishing, LLC. Heyneman, S. (1999). The sad story of UNESCO's education statistics. International Journal of Education Development, 19, 65-74.

Hong, H. (2012). Trends in mathematics and science performance in 18 countries: Multiple regression analysis of the cohort effects of TIMSS 1995-2007. Education Policy Analysis Archives, 20(33), 1-23.

Horvath, P. (1987). A look at the Second International Mathematics Study results in the U.S.A. and Japan. The Mathematics Teacher, 80(5), 359-368.

Huang, Y., \& Jin, X. (2018). Innovative college english teaching modes based on Big Data. Educational Sciences: Theory \& Practice, 18(6), 3428-3434.

IEA. (2019a). Other IEA studies. Retrieved from https://www.iea.nl/other-iea-studies. Accessed on April 21, 2019.

IEA. (2019b). FIMS. First International Mathematics Study. Retrieved from https://www.iea.nl/fims. Accessed on April 21, 2019.

IEA. (2019c). Other IEA studies. Retrieved from https://www.iea.nl/other-iea-studies. Accessed on April 21, 2019.

Jessop, B. (1998). The rise of governance and the risks of failure: The case of economic development. International Social Science Journal, 155, 29-46.

Jessop, B. (2000). The crisis of the national spatio-temporal fix and the tendential ecological dominance of globalizing capitalism. International Journal of Urban and Regional Research, 24(2), 323-360. 
Jessop, B. (2008). The rise of governance and the risks of failure: The case of economic development. International Social Science Journal, 50, 29-45.

Jones, P. W. (2004). Taking the credit: Financing and policy linkages in the education portfolio of the world bank. In G. Steiner-Khamsi \& T. S. Popkewitz (Eds.), The global politics of educational borrowing and lending (pp. 188-200). New York, NY: Teachers College Press.

Jules, T. D. (2012). Neither world polity nor local or national societies: Regionalization in the global SouthThe Caribbean community. Berlin: Peter Lang.

Jules, T. D. (2015a). "Educational regionalization" and the gated global: The construction of the Caribbean educational policy space. Comparative Education Review, 59(4), 638-665.

Jules, T. D. (2015b). A stitch in time saves Caribbeanization: Meta-steering and strategic coordination in an era of Caribbean trans-regionalism. Caribbean Journal of International Relations and Diplomacy, $3(2), 37-57$.

Jules, T. D. (2016). The new global educational policy environment: Gated, regulated and governed. Bingley: Emerald Publishing.

Jules, T. D. (2018). Educational regime complexity: Nested governance and multistakeholderism in the fourth industrial revolution. International Perspectives on Education and Society, 34, 139-158.

Jules, T. D., \& Jefferson, S. S. (2016). The next educational bubble: Educational brokers and education governance mechanisms: Who governs what! In T. D. Jules (Ed.), The global educational policy environment in the fourth industrial revolution: Gated, regulated and governed (Public Policy and Governance, Volume 26, pp. 123-147). Bingley: Emerald Group Publishing Limited.

Kassim, H. (2016). Toward the development of a gender equity scorecard: Exploring the possibility for collaborative gender governance at the University of the West Indies. In T. D. Jules (Ed.), The globaleducational policyenvironmentinthefourthindustrial revolution (pp.85-122). Bingley: Emerald Publishing.

Kooiman, J., Bavinck, M., Chuenpagdee, R., Mahon, R., \& Pullin, R. (2008). Interactive governance and governability: An introduction. Journal of Transdisciplinary Environmental Studies, 7(1), $1-11$.

Kum, H. C., Joy Stewart, C., Rose, R. A., \& Duncan, D. F. (2015). Using Big Data for evidence based governance in child welfare. Children \& Youth Services Review, 58, 127-136.

Laney, D. (2001). 3-D data management: Controlling data volume, velocity and variety. Application delivery strategies. META Group Inc. Retrieved from https://blogs.gartner.com/doug-laney/ files/2012/01/ad949-3D-Data-Management-Controlling-Data-Volume-Velocity-and-Variety. pdf

Levi-Faur, D. (Ed.). (2012). The Oxford handbook of governance. Oxford: Oxford University Press

Li, G., Feng, J., Chin Ooi, B., Wang, J., \& Zhou, L. (2011). An effective 3-in-1 keyword search method over heterogeneous data sources. Information Systems, 36(2), 248-266.

Lindblad, S., Pettersson, D., \& Popkewitz, T. (2018). Getting the numbers right: An introduction. In S. Lindblad, D. Pettersson, \& T. Popkewitz (Eds.), Education by the numbers and the making of society: The expertise of international assessments (pp. 1-20). New York, NY: Routledge.

Liu, H. (2018). Education systems, education reforms, and adult skills in the Survey of Adult Skills (PIAAC). OECD Education Working Papers No. 182. Paris, France: OECD.

Loizou, B. (2017). The rise of the intelligence economy: Where to next? Retrieved from https://www. bandt.com.au/marketing/rise-intelligence-economy

Maroy, C. (2009). Convergences and hybridization of educational policies around 'post-bureaucratic' models of regulation. Compare, 39(1), 71-84.

Marra, M. (2018). The ambiguities of performance-based governance reforms in Italy: Reviving the fortunes of evaluation and performance measurement. Evaluation \& Program Planning, 69, 173-182. https://doi-org.flagship.luc.edu/10.1016/j.evalprogplan.2017.02.006

Martens, K. (2007). How to become an influential actor: The 'comparative turn' in OECD education policy. In K. Martens, A. Rusconi, \& K. Leuze (Ed.), New arenas of education governance (pp. 40-56). London: Routledge.

Martin, M., \& Mullis, I. (2013). TIMSS and PIRLS 2011: Relationships among reading, mathematics, and science achievement at the fourth grade - Implications for early learning. Amsterdam, The Netherlands: International Association for the Evaluation of Educational Achievement..

Meyer, H. D., \& Benavot, A. (Eds.). (2013). PISA, power, and policy: The emergence of global educational governance. Oxford: Symposium Books Ltd. 
Mølstad \& Pettersson. (2018). Who governs the numbers? The framing of educational knowledge by TIMSS research. In S. Lindblad, D. Pettersson, \& T. Popkewitz (Eds.), Education by the numbers and the making of society: The expertise of international assessments (pp. 166-184). New York, NY: Routledge.

Mundy, K. (1998). Educational multilateralism and world (dis)order. Comparative Education Review, 42(4), 448-478.

Mundy, K. (1999). Educational multilateralism in a changing world order: UNESCO and the Limits of the Possible. International Journal of Educational Development 19(1), 27-52.

OECD. (2016). Teaching and Learning International Survey TALIS 2018 survey. Paris, France: OECD

OECD. (2017). PISA 2015 assessment and analytical framework: Science, reading, mathematic, financial literacy and collaborative problem solving (Revised ed.). Paris, France: OECD Publishing.

OECD. (2018). Oslo Manual 2018: Guidelines for collecting, reporting and using data on innovation (4th ed.). Paris, France: OECD Publishing.

Paccagnella, M. (2016). Literacy and numeracy proficiency in IALS, ALL and PIAAC. OECD Education Working Papers, No. 142. Paris, France: OECD.

Parreira do Amaral, M. (2006). The influence of transnational organizations on national education systems. Frankfurt/M, Germany: Peter Lang.

Parreira do Amaral, M. (2010). Regime theory and educational governance: The emergence of an international education regime. International Educational Governance International Perspectives on Education and Society, 3679, 57-78.

Porter, T. M. (2018). Politics by the numbers. In S. Lindblad, D. Pettersson, \& T. S. Popkewitz (Ed.), Education by the numbers and the making of society (pp. 23-35). London: Routledge

Probst, L., Frideres, L., Cambier, B., Ankeraa, J., \& Lide', L. (2016). Servitisation: Service and predictive maintenance contracts. Brussels, Belgium: European Union. Retrieved from http:// ec.europa.eu/DocsRoom/documents/16594/attachments/1/translations/en/renditions/native

Robertson, S. L., Bonal, X., \& Dale, R. (2002). GATS and the Education Service Industry: The Politics of Scale and Global Reterritorialization. Comparative Education Review, 464,472-495.

Robertson, S. L., Mundy, K. E., Verger, A., \& Menashy, F. (2012). Public private partnerships in education: New actors and modes of governance in a globalizing world. Cheltenham: Edward Elgar.

Robitaille, D. (1990). Achievement comparisons between the first and second IEA studies of mathematics. Educational Studies in Mathematics, 21(5), 395-414.

Schleicher, A. (2011). Lessons from the world on effective teaching and learning environments. Journal of Teacher Education, 62(2), 202-221.

Sobe, N. W. (2018). Problematizing comparison in a post-exploration age: Big Data, educational knowledge, and the art of criss-crossing. Comparative Education Review, 62(3), 325-343.

Steiner-Khamsi, G. (2014). Cross-national policy borrowing: Understanding reception and translation. Asia Pacific Journal of Education, 34(2), 153-167.

Steiner-Khamsi, G. (2016). Standards are good (for) business: Standardised comparison and the private sector in education. Globalisation, Societies and Education, 14(12), 161-182.

The Atlantic. (2018). Human capital: The backlash Against Screen Time at School Combining education and technology is great: Until it's not. Retrieved from https://www.theatlantic.com/ education/archive/2018/11/screen-time-backlash/567934/

Thorn, W. (2009). International adult literacy and basic skills survey in the OECD region. OECD Education Working Papers No. 26. OECD, Paris, France.

UNESCO. (2019.). About us. Retrieved on April 21, 2019 from https://en.unesco.org/gem-report/about

Williamson, B. (2017). Big Data in education: The digital future of learning, policy and practice. London: SAGE Publications. 